\title{
Creative industry as a key creative component of the Slovak economy
}

\author{
Daniela Rybarova ${ }^{1, *}$ \\ ${ }^{1}$ University of Economics in Bratislava, Faculty of Business Management, Dolnozemska cesta 1, Bratislava, \\ Slovak republic
}

\begin{abstract}
The global economy is understood as an economy of information, knowledge, creativity, networks and services. The creation of value in the economy is involved in the economic, social and cognitive mechanisms. The economic mechanism emphasizes the processes of cooperation and production, the social mechanism, in turn, communication and marketing techniques, the cognitive mechanism is based on human imagination and interpretation. Under the cognitive mechanism is meant creativity, the ability to bring new motive, ideas. Cognitive mechanisms are in value creation process complementary to economic and social mechanisms and they are capable of producing value separately. One of the approaches to measuring creativity is to define and analyse creative industries. The creative industries are industries in which "combine and overlap the fields of art, culture, business and technology. They create a cycle of creation, production and distribution, using their intellectual capital as primary capital [1]. The contribution of the creative industry lies in its cross-sectoral dimension with minimal territorial constraints. The article will focus on the definition of creative industries and the analysis of creative industries in the Slovakia. The method used was the analysis of trends in the form of percentage year-on-year change. The creative industry is the sensitive on the state and development of the economy in Slovakia.
\end{abstract}

\section{Introduction}

The globalization of the world economy leads to significant economic, scientific, technical and geopolitical changes. What causes a number of consequences that change the established practices? Traditional factors of economic development - land, labor, capital are receding into the background and knowledge is gaining prominence. Knowledge management and its resulting product - intellectual capital is becoming a source of competitive advantage, which is confirmed by many studies [2]. More in [3] the study is based on the framework developed by the World Intellectual Property Organization, so as to make international comparisons possible. Specifically, the study compares the contribution of the core copyright-based industries in Canada with the United States and the European Union. Invention, innovation, creativity and talent are becoming increasingly important factors for the economy and can also be instrumental in stabilizing the economy

\footnotetext{
*Corresponding author: daniela.rybarova@euba.sk
} 
in times of crisis. The creative economy is a natural environment for innovative ideas and the development and exploitation of creative potential. Creativity, together with an adequate organizational culture, is also an essential prerequisite for creating innovation [4].

Creativity without innovation can exist, but innovation cannot arise unless there is creative creation at some point. It can be assumed that industries in the 21 st century will increasingly depend on knowledge generation through creativity and innovation [5].The results of further research highlight the feasibility of stimulating innovation processes and employment through information and communications technology policies among strategic service sub-sectors and creative industries in emerging digital ecosystems [6].

Creativity can be characterized in particular as the realization of ideas and ideas, which are becoming an important input of the economy. Creativity is becoming a key factor in economic development [7], which, due to its limitlessness compared to other resources, plays a very important role in developed economies. Creativity [8] can add value to organizations after it is perceived, evaluated, and eventually adopted. The output of creativity can now generate more significant benefits than other industries. The link between culture and the economy results in the creative industry [9] what is the engine of the economy. The creative economy [10], as a set of creative industries, represents a mutual association and knowledge-centered sectors focused on the creation and exploitation of intellectual property. Applying unique ideas can make a significant contribution to productivity growth, while exploiting creativity places greater demands on business management. Creative organizations are characterized by a tension between creative work and business. For example, research [11] mobilized Boltanski and Thévenot's Economies of Worth framework to explore, through the concept of compromise, how this tension is accommodated in the management of creative workers. Another study deals with examining this, whether bonding or bridging ties are more beneficial for acquiring knowledge that is conducive to individual creativity [12].

The notion of creative industry implies a number of areas (mainly the art of science and, last but not least, culture) and at the same time it affects the social demand for a change in the perception of the concept of industry, which is still understood only in terms of pure production characteristics. In this context, industry must be seen as an exploitation chain that is already created by creating the conditions for creative activity then includes creative activity, production, reproduction, presentation, representation, including export, storage, archiving and recovery.

Sectors of the creative industries are formed by the business activities based on individual creativity, skill and talent. They are also the ones that have the potential for capital formation and job creation through the use of intellectual property. The sectors mainly include advertising, architecture, art, antique shops, computer and video games, crafts, design, fashion design, film and video, music, performing arts, publishing, software, television and radio. These areas are mainly related to the high added value and significant impact on the quality of people's lives [13].

To be able to create the full definition framework of creative industry for the Slovak Republic, it is important to monitor the development in the definition of the creative industry and the modelling of tools for the support of the creative economy from the European Union point of view [14].The definition of the creative industry also takes into account the requirements of Eurostat resulting from the ESSnet-Culture Final Report 2011 (material produced by Eurostat's TF 1 working group, aiming at harmonizing the methodology of European statistics on culture and creative industries) at least partially comparable data from individual European countries (Table 1). 
Table 1. Proposed delineation of the cultural \& creative sector [15]

\begin{tabular}{|c|c|c|c|}
\hline CIRCLES & SECTORS & SUB- SECTORS & CHARACTERISTIC \\
\hline \multicolumn{4}{|c|}{ “THE CULTURAL SECTOR" } \\
\hline \multirow[b]{3}{*}{$\begin{array}{l}\text { CORE ARTS } \\
\text { FIELD }\end{array}$} & Visual arts & $\begin{array}{c}\text { Crafts Paintings - Sculpture } \\
- \text { Photography }\end{array}$ & \multirow{3}{*}{$\begin{array}{l}\text { - Non industrial activities. } \\
\text { - Output are prototypes and } \\
\text { "potentially copyrighted works" } \\
\text { (i.e.these works have a high } \\
\text { density of creation that would be } \\
\text { eligible to copyright but they are } \\
\text { however not systematically } \\
\text { copyrighted, as it is the case for } \\
\text { most craft works, some } \\
\text { performing arts productions and } \\
\text { visual arts, etc). }\end{array}$} \\
\hline & $\begin{array}{l}\text { Performing } \\
\text { arts }\end{array}$ & $\begin{array}{c}\text { Theatre - Dance - Circus - } \\
\text { Festivals. }\end{array}$ & \\
\hline & Heritage & $\begin{array}{c}\text { Museums - Libraries - } \\
\text { Archaeological sites - } \\
\text { Archives. }\end{array}$ & \\
\hline \multirow[b]{3}{*}{ CIRCLE 1: } & $\begin{array}{c}\text { Film and } \\
\text { Video }\end{array}$ & & \multirow{5}{*}{$\begin{array}{l}\text {-Industrial activities aimed at } \\
\text { massive reproduction. } \\
\text {-Outputs are based on copyrig } \\
\text {-ht. }\end{array}$} \\
\hline & $\begin{array}{l}\text { Television and } \\
\text { radio }\end{array}$ & & \\
\hline & Video games & & \\
\hline \multirow[t]{2}{*}{$\begin{array}{l}\text { CULTURAL } \\
\text { INDUSTRIES }\end{array}$} & Music & $\begin{array}{l}\text { Recorded music market - } \\
\text { Live music performances - } \\
\text { revenues of collecting } \\
\text { societies in the music sector }\end{array}$ & \\
\hline & $\begin{array}{l}\text { Books and } \\
\text { press }\end{array}$ & $\begin{array}{l}\text { Book publishing - } \\
\text { Magazine and press } \\
\text { publishing }\end{array}$ & \\
\hline \multicolumn{4}{|c|}{ "THE CREATIVE SECTOR" } \\
\hline \multirow{3}{*}{$\begin{array}{l}\text { CIRCLE 2: } \\
\\
\text { CREATIVE } \\
\text { INDUSTIES } \\
\text { AND } \\
\text { ACTIVITIES }\end{array}$} & Design & $\begin{array}{c}\text { Fashion design, graphic } \\
\text { design, interior design, } \\
\text { product design }\end{array}$ & \multirow{3}{*}{$\begin{array}{l}\text {-Activities are not necessarily } \\
\text { industrial, and may be prototypes. } \\
\text { - Although outputs are based on } \\
\text { copyright, they may include other } \\
\text { intellectual property inputs } \\
\text { (trademark for instance). } \\
\text { - The use of creativity (creative } \\
\text { skills and creative people } \\
\text { originating in the arts field and in } \\
\text { the field of cultural industries) is } \\
\text { essential to the performances of } \\
\text { these non cultural sectors. }\end{array}$} \\
\hline & Architecture & & \\
\hline & Advertising & & \\
\hline $\begin{array}{l}\text { CIRCLE 3: } \\
\text { RELATED } \\
\text { INDUSTRIES }\end{array}$ & $\begin{array}{c}\text { PC } \\
\text { manufacturers, } \\
\text { MP3 player } \\
\text { manufacturers, } \\
\text { mobile } \\
\text { industry, etc... }\end{array}$ & & $\begin{array}{l}\text {-This category is loose and } \\
\text { impossible to circumscribe on the } \\
\text { basis of clear criteria. } \\
\text { It involves many other economic } \\
\text { sectors that are dependent on the } \\
\text { previous "circles", such as the } \\
\text { ICT sector. }\end{array}$ \\
\hline
\end{tabular}

The close link between the economic and social growth of the communities concerned is an integral part of the development of the cultural and creative industries. Indeed, the sector remains inextricably linked to the environment in question: clusters draw on unique local socio-economic relationships, sector workers are rooted in the territory and there is a close link between the education and training sectors [16]. 


\section{Methods}

The basic question that we want to answer is the development of the cretical industry in Slovakia compared to the overall development of the national economy. Starting from the assumption that globalization affects the national economies of all countries. We are looking for an answer to the impact of globalization on the structure of the national economy of Slovakia with a focus on the creative industry. Another assumption on which we were based was the expectations of economic theories in relation to the creative industry as an important factor for future development with limited resources. Similarly, the theory reasonably assumes that the creative industry could grow in times of economic crisis. In order to be able to answer the question also with regard to given assumptions and after collecting available statistical data, we also chose from the descriptive statistics methods basic analysis of trends and graphical analysis.

We have examined the EUROSTAT statistical databases [17] and UNCTADstat and selected EUROSTAT for completeness. Data on enterprises active in the cultural sectors come from the domains "Structural Business Statistics" (SBS) and "Business demography" (BD). In addition to those economic indicators on cultural businesses, data from PRODCOM provide the volume (in euros) of sold production of cultural goods. SBS cover the business economy, including the following cultural activities: C18 Printing and reproduction of recorded media; C3212 Manufacture of jewellery and related articles, C322 Manufacture of musical instruments, G4761 Retail sale of books in specialised stores,G4762 Retail sale of newspapers and stationery in specialised stores, G4763 Retail sale of music and video recordings in specialised stores, J5811 Book publishing, J5813 Publishing of newspapers, J5814 Publishing of journals and periodicals, J5821 Publishing of computer games; J59 Motion picture, video and television programme production, sound recording and music publishing activities, J60 Programming and broadcasting activities, J6391 News agency activities, M7111 Architectural activities, M741 Specialised design activities, M742 Photographic activities, M743 Translation and interpretation activities, N7722 Renting of video tapes and disks. BD statistics cover the following cultural market-oriented activities: J59 Motion picture, video and television programme production, sound recording and music publishing activities, J60 Programming and broadcasting activities; 7111 Architectural activities; M741 Specialised design activities; M742 Photographic activities, M743 Translation and interpretation activities; N7722 Renting of video tapes and disks, $R 90$ Creative, arts and entertainment activities and R91 Libraries, archives, museums and other cultural activities are collected on a voluntary basis. Therefore, data are missing for some countries.

Given the economic activities listed above, in comparison with Table 1, it can be stated that these are data from the cultural and creative industries. There is no clear view of the overall designation of the sectors mentioned. In some cases, all activities are labelled as a creative industry, consisting of a cultural and creative industry, or a cultural industry broken down into a cultural and creative industry. It is also possible to examine each part separately. For the purposes of our analysis, we have examined both of these components together.

Data examined: turnover or gross premiums written - million euros, value added at factor cost - million euros, enterprises - number and persons employed - number, imports and exports. The method used was the analysis of trends in the form of percentage year-onyear change. Line graphs with markers were used for graphical analysis to indicate the values of each data and to display trends over time. 


\section{Result}

Comparing the development of annual percentage changes of selected indicators for total business economy expect financial and insurance activities and selected branches of cultural and creative industries showed significant differences in their response to the development of the national economy. Total business economy did not record major fluctuations in development up to the period of financial crisis, especially in the number of enterprises. In Figure 1, the percentage of changes in the number of enterprises in 2010 was up to $550 \%$, but this could also be due to incomplete data for the previous period

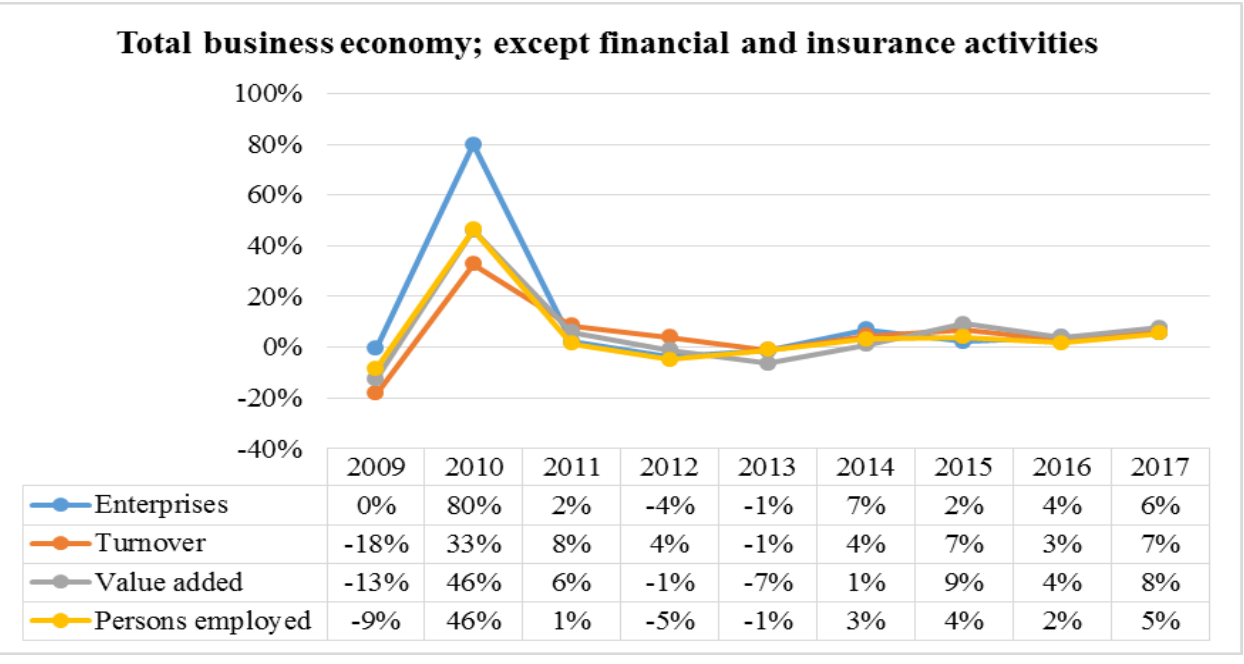

Fig. 1. Development of selected economic indicators - total business economy [17]

The balance of development may be affected by the greater diversity of e-activities involved in terms of sector cyclicity. Selected areas of creative industries (cultural and creative) respond more dynamically to events in the national economy (Figure 2).

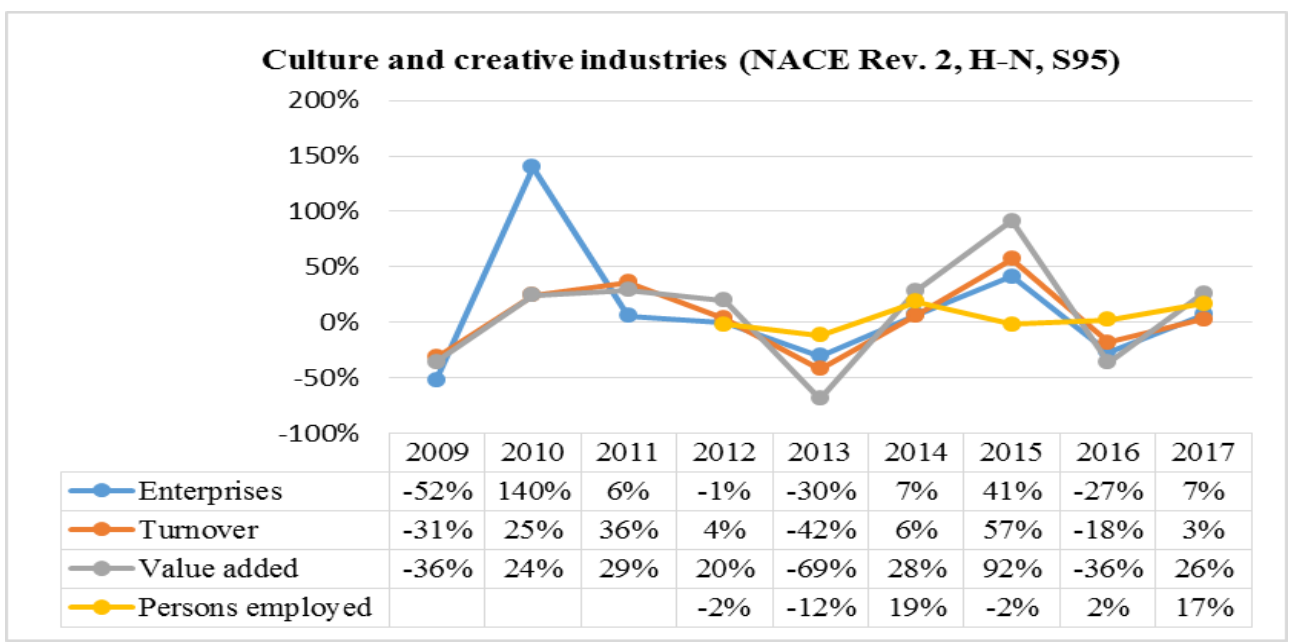

Fig. 1. Development of selected economic indicators - total business economy [17]

Again, we reduced the percentage change in the number of businesses in 2010 to keep the chart clear. The actual change in the number of enterprises in $2010 \mathrm{w}$ as almost $1500 \%$, 
which is attributable to incomplete data before 2010. The percentage change reflects the dynamics of the creative sector. In addition to the number of enterprises, significant changes (a 69\% decrease in 2013 and a 92\% increase in 2015) were recorded in value added. Creative industry also responded sensitively to the second wave of the financial crisis in 2012, when all indicators fell sharply in 2013. On the basis of this partial assessment it can be stated that the creative industry (culture and creative) reacts sensitively to changes in the national and impact of globalization in the national economy and the impact of globalization in the national economy can respond flexibly to the deterioration of the economy by dissolving the business. On the other hand, new businesses are entering this sector considerably faster. Labor productivity measured by the turnover per worker as well as the value added per worker in the creative industry is lower than the average for all business economy in all analyzed periods. However, it should be added that data for the creative industry do not cover all economic activities belonging to this sector.

Table 2. Imports and exports - all products [17]

\begin{tabular}{|c|c|c|c|c|c|c|c|c|c|c|}
\hline \multicolumn{8}{|c|}{ Slovakia - all products - all countries of the world - in millions of ECU/EURO } \\
\hline TIME & $\mathbf{2 0 0 8}$ & $\mathbf{2 0 0 9}$ & $\mathbf{2 0 1 0}$ & $\mathbf{2 0 1 1}$ & $\mathbf{2 0 1 2}$ & $\mathbf{2 0 1 3}$ & $\mathbf{2 0 1 4}$ & $\mathbf{2 0 1 5}$ & $\mathbf{2 0 1 6}$ & $\mathbf{2 0 1 7}$ \\
\hline & 50 & 39 & 49 & 57 & 60 & 61 & 61 & 66 & 68 & 73 \\
Imports & 253 & 898 & 050 & 358 & 242 & 543 & 689 & 167 & 216 & 685 \\
\hline & 48 & 40 & 48 & 57 & 62 & 64 & 65 & 67 & 70 & 74 \\
Exports & 370 & 208 & 777 & 350 & 743 & 566 & 081 & 845 & 070 & 726 \\
\hline $\begin{array}{c}\text { Trade } \\
\text { balance }\end{array}$ & -1 & & & & & & & & & \\
\end{tabular}

Then we analyzed imports and exports. Data for trade in cultural goods by product were available for the creative industry (Table 2 and Table 3). Trade balance in the all business economy is positive except for 2008, 2020 and 2011 due to the economic crisis, which mainly affected the automotive industry.

Table 3. Imports and exports - trade in cultural goods by product [17]

\begin{tabular}{|c|c|c|c|c|c|c|c|c|c|c|}
\hline \multicolumn{8}{|c|}{ Slovakia - culture and creative industries - trade in cultural goods by product - } \\
all countries of the world - in millions of ECU/EURO \\
\hline TIME & $\mathbf{2 0 0 8}$ & $\mathbf{2 0 0 9}$ & $\mathbf{2 0 1 0}$ & $\mathbf{2 0 1 1}$ & $\mathbf{2 0 1 2}$ & $\mathbf{2 0 1 3}$ & $\mathbf{2 0 1 4}$ & $\mathbf{2 0 1 5}$ & $\mathbf{2 0 1 6}$ & $\mathbf{2 0 1 7}$ \\
\hline Imports & 254 & 255 & 200 & 244 & 231 & 176 & 228 & 287 & 275 & 268 \\
\hline Exports & 231 & 227 & 179 & 194 & 190 & 187 & 201 & 246 & 255 & 303 \\
\hline Trade balance & -23 & -29 & -21 & -49 & -42 & 11 & -28 & -41 & -20 & 35 \\
\hline
\end{tabular}

Import and export trade in cultural goods by product (Table 3 ) has a negative balance in each year except 2013 and 2017.

The sharp decline in times of crisis is replaced by a rapid growth at a time when the crisis has subsided. Based on the results of the trend analysis, it can be stated that the creative industry is sensitive to economic fluctuations.

\section{Discussion}

The creative industry is characterized by significant cross-sectoral, representation of small businesses and self-employment (the area with the highest self-employment rate) and the need for relatively low initial capital. Since the creative economy is a specific segment of economic processes and the business environment, economic theory can also help its 
development. Creating non-standard business models, new models of work organization and the resulting infrastructure, what take into account the differences in the economic chain when creating creative products and activities.

There is lot of articles being written that are dealing with effectivity or are covering certain part of business management. There are numbers of articles that address certain areas of management and efficiency of creative businesses. For example, article [18] who claims that organizations, especially within the creative industries, are increasingly faced with limitations while applying classical strategy theories due to changes in social and economic environmental factors. The purpose of their article is to offer a theoreticalconceptual framework for the strategic design of small firms in the creative industries. Their research explores the effect of the implementation and intensive use of broadband on the labour demand induced by the innovative behaviour of Peruvian firms of creative industries (CI) in comparison to Knowledge Intensive Business Services (KIBS) and Services companies. Next article [19] building upon the key experiences of advertising creatives, a triadic structure of advertising creatives' emergent role that was identified from the analyses of in-depth interview data in different types and levels of current advertising organizations.

A striking feature of the 2010 s and after has been significant growth in the number of creative industries courses being offered worldwide, seemingly independently of the fortunes of creative industries as a policy concept [17]. Their paper undertakes an analysis of the growth in such courses in the United Kingdom and Australia, reviewing course content.

\section{Conclusion}

The future of the creative sector in Slovakia depends mainly on the actors themselves and their ability to respond to current economic and social trends in the world. Rapidly developing areas (especially in the design, gaming industry, but also audiovisual and other sub-sectors) show that the most important thing is the invention of the players themselves, their ability to cooperate and to organize internally. It is important that the state and public policies also help in this process.

This paper is an output of the science project VEGA č. 1/0340/19, „,Podnikatel'ský rozmer subjektov kreatívneho priemyslu v kontexte inovácií a inteligentného rastu“, project share is $100 \%$;

\section{References}

1. UNCTAD, Annual 2018 report Avaliable at: https://unctad.org/annualreport/2018/Pages/index.html

2. P. Kline, N. Petkova, H. Williams, O. Zidar, Who Profits from Patents? Rent-Sharing at Innovative Firms. The Quarterly Journal of Economics 134, 1343-1404 (2019)

3. R. Nikzad, R. Solomon, The value of copyright-based industries in Canada. Creative Industries Journal 12, 204-228 (2019)

4. P. Aghion, U. Akcigit, A. Bergeaud, R. Blundell, D. Hemous, Innovation and Top Income Inequality. The Review of Economic Studies 86, 1-45 (2019)

5. C. Landry, F. Bianchini, The Creative City. (Demos in Association with Comedia, London, 1st ed., 1995). 
6. R. C. Vergara, P. M. Feldman, Impact of broadband uses on labour demand derived from the innovative behaviour of firms in creative industries. Creative Industries Journal 11, 278-305 (2018)

7. M. Mundelius, The reliance of Berlin's creative industries on milie-us. (VDM Verlag dr. Mueller, Saabrücken, 2008)

8. J. Zhou, X. M. Wang, D. Bavato, S. Tasselli, J. Wu, Understanding the Receiving Side of Creativity: A Multidisciplinary Review and Implications for Management Research. Journal of Management 45, 2570-2595 (2019)

9. J. O'Connor, L. Kong, Creative economies, creative cities: Asi-an-European perspectives. (Springer, Dordrecht, 2009)

10. H. Colette, Enterpreneurship in the creative industry: an internatio-nal perspective. (Edward Elgar, Cheltenham, 2007)

11. J. Berube, Ch. Demers, Creative organizations: when management fosters creative work. Creative Industries Journal 12, 314-340 (2019)

12. G. Soda, D. Stea, T. Pedersen, Network Structure, Collaborative Context, and Individual Creativity. Journal of Management 45, 1739-1765 (2019)

13. Slovak Culture Profile, Definicia kreativneho priemyslu. Avaliable at: https://profil.kultury.sk/sk/kreativny-priemysel/ (2019)

14. Neulogy, Sprava o stave a potenciali kreativnehoo priemyslu na Slovensku. Avaliable at: http://www.culture.gov.sk/posobnost-ministerstva/kreativny-priemysel-165.html (2013).

15. KEA, with the support of: MKW Wirtschaftsforschung, Turun Kauppakorkeakoulu. The Economy of Culture. 355. Avaliable at: https://ec.europa.eu/assets/eac/culture/library/studies/cultural-economy_en.pdf (2006)

16. EESC, Opinion of the European Economic and Social Committee on 'Unlocking the potential of cultural and creative industries (Green Paper)' $\mathrm{COM}(2010) 183$ final, 1-15, Avaliable at: www.culturegov.sk>extdoc $>$ stanovisko_ep (2010)

17. EUROSTAT, Avaliable at: https://ec.europa.eu/eurostat (2019)

18. S. Schmidt, D. Schreiber, M. Ch. Bohnenberger, C.M.P. Pinheiro, Strategic design in small creative industry firms. Creative Industries Journal 11, 306-321 (2018)

19. P. Y. Lee, K. W. Lau, A new triadic creative role for advertising industry: a study of creatives' role identity in the rise of social media advertising. Creative Industries Journal 11, 137-157 (2018)

20. T. Flew, From policy to curriculum: drivers of the growth in creative industries courses in the UK and Australia. Creative Industries Journal 12, 167-184 (2019) 